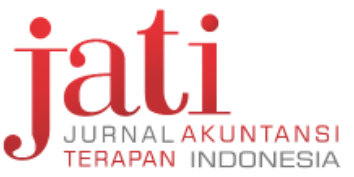

Jati: Jurnal Akuntansi Terapan Indonesia Vol 1 No 2 Hal 52-63 Oktober 2018

\title{
Mengevaluasi Sistem Pengukuran Kinerja di Instansi Publik: Studi pada Badan Penanggulangan Bencana Daerah
}

\author{
http://journal.umy.ac.id/index.php/jati \\ C) $2018 \mathrm{JATI}$. All rights reserved \\ DOI: 10.18196/jati.010206
}

\section{DATA ARTIKEL:}

Diterima: 8 Mei 2018

Direviu: 9 Juli 2018

Direvisi: 16 Juli 2018

Disetujui: 1 Agustus 2018

TOPIK ARTIKEL:

Akuntansi Sektor Publik

\author{
FIKO RAHARDITO BASKORO*, RUSDI AKBAR \\ Universitas Gajah Mada \\ *Email korespondensi: fikobaskoro@gmail.com
}

\begin{abstract}
ABSTRAK: Penelitian ini bertujuan untuk mengevaluasi indikator kinerja yang disusun BPBD khususnya di DIY serta mengidentifikasi faktor-faktor yang timbul dalam penyusunan indikator kinerja. Desain penelitian ini meng-gunakan pendekatan deskriptif kualitatif. Tek-nik analisis data mengacu pada teknik analisis Hutter-Hennink yang terdiri atas tahap pengembangan koda, ulasan mendalam, perbandingan, kategorisasi, dan konseptualisasi. Teknik pengumpulan data menggunakan metoda dokumentasi, wawancara, dan studi pustaka. Hasil evaluasi cetak biru kinerja menunjukkan bahwa indikator kinerja yang disusun BPBD DIY memiliki kesesuaian logis serta munculan yang berbasis pada dampak untuk masyarakat. Namun, indikator kinerja BPBD DIY belum ber-orientasi pada kualitas baik upaya maupun hasil serta belum mengidentifikasikan penyedia layanan dalam aktivitasnya. Adapun munculan desa tangguh tetap terhitung menunjukkan kesesuaian logis karena lingkup desa di DIY sebesar 75\% dan satuan wilayah lainnya sudah menjadi fokus organisasi lain, berdasarkan hasil triangulasi dokumen dengan wawancara. Selanjutnya, berdasarkan kategorisasi koda-koda yang disusun, dapat disimpulkan bahwa terdapat beberapa fak-tor yang hadir dalam penyusunan indikator kinerja BPBD DIY. Faktor-faktor tersebut yakni dukungan (pen-dampingan dan pelatihan), persepsi, proses pembentukan, serta pengawasan dan apresiasi (monev dan "hadiah-hukuman" dari Guber-nur) yang berperan bagi komponen organisasi (utamanya personel) untuk menyusun SAKIP sekaligus merealisasi tujuan organi-
\end{abstract}

sasi yakni penurunan risiko bencana. Selain itu, peneliti juga menemukan gejala isomor-fisma normatif di dalam sistem pengukuran kinerja BPBD DIY.

Kata Kunci: Cetak Biru Kinerja, Empat Kuadran Friedman, Indikator Kinerja, Isomorfisma Normatif, Model Logika

ABSTRACT: This research aimed to examine the association between BPBD especially in Yogyakarta Special Region's performance indicator by using logic model approach and then evaluate whether its performance measurement system capable to form organizational goal congruence. The research design of this research is qualitative descriptive approach. Analysis conducted based on Hutter-Hennink analysis technique with these steps: code development, thick description, comparison, categorization, and conceptualization. Data collected by using document analysis, interview, and literature review. The performance blueprint results showed that performance indicator which designed by BPBD DIY are logical and have community-based outcomes. However, it isn't yet oriented into quality, either effort or effect and it's not yet identified the providers in their activities. The resilience of the village is still calculated to show logical compatibility because $75 \%$ of village and other regional units' scope in DIY have become the focus of other organizations, based on the results of document triangulation with interviews. Next, researcher find the PMSs in BPBD DIY have several factors: enabling the organization to achieve goal congruence which based on researcher's finding on support (help and training), perception, process in making SAKIP, and oversight and appreciation (monitoring and evaluation, and reward-punishment). Program and activities congruent with output and outcome which resulted to organizational aim: the increase in Yogyakarta's Special Region endurance by disaster risk reduction (DRR). Beside that, researcher also found a normative isomorphism phenomenon in BPBD DIY's PMSs.

Keywords: Performance Blueprint, Friedman's four Quadrant, Performance Indicator, Normative Isomorphism, Logic Model 


\section{SITASI ARTIKEL:}

Baskoro, F. R., \& Akbar, R. (2018). Mengevaluasi Sistem Pengukuran Kinerja di Instansi Publik: Studi pada Badan Penanggulangan Bencana Daerah. Jati: Jurnal Akuntansi Terapan Indonesia, 1(2), 52-63.

\section{PENDAHULUAN}

Undang-Undang Dasar Negara Republik Indonesia Tahun 1945 mengamanatkan bahwa Negara Kesatuan Republik Indonesia bertanggung jawab untuk memberikan perlindungan terhadap kehidupan dan penghidupan dalam rangka mewujudkan kesejahteraan umum, salah satunya perlindungan terhadap bencana. Penanggulangan dan pengurangan risiko bencana merupakan rencana pemerintah (Rencana Pembangunan Jangka Menengah Nasional 2015-2019) yang dilandasi dari kenyataan bahwa Indonesia terpapar oleh berbagai fenomena alam yang berpotensi menimbulkan risiko bencana. Hal ini menjadikan Indonesia dikenal sebagai sebagai "supermarket bencana" meski dianggap cukup baik dalam penanggulangannya (Sasongko, 2014).

Pemerintah membentuk Badan Nasional Penanggulangan Bencana (BNPB) sebagai lembaga pemerintah non departemen setingkat menteri (Undang-Undang Nomor 27 Tahun 2007 Tentang Penanggulangan Bencana). Selanjutnya untuk lingkup provinsi/kabupaten/kota dibentuklah Badan Penanggulangan Bencana Daerah (Halim, 2016) yang berada di bawah gubernur/bupati/walikota. Lebih lanjut, disebutkan dalam Rencana Nasional BNPB bahwa dalam penanggulangan bencana terdapat enam aspek capaian di mana salah satunya adalah aspek kerangka regulasi dan kelembagaan (2014). Salah satu realisasi pada aspek kelembagaan adalah melalui penyusunan rencana strategik, program dan kegiatan, penganggaran, penetapan kinerja, pelaksanaan, serta evaluasi pelaksanaan dan kinerja.

Realisasi BNPB dan BPBD dalam kelembagaan tersebut sebenarnya merupakan bagian dari Sistem Pengendalian Manajemen (SPM), di mana SPM ini dapat diterapkan di organisasi kepemerintahan (Anthony \& Young, 2007, hal. 48-49). Akan tetapi, perbedaan karakteristik organisasi kepemerintahan yang tidak berorientasi laba dengan yang berorientasi laba dan manufaktur memunculkan sejumlah isu. Salah satunya pada sistem pengukuran kinerja (Balabonienė \& Večerskienè, 2015). Secara lebih spesifik, sistem pengukuran kinerja menjadi elemen kunci dalam penerapan New Public Management (NPM) sebagai media pertanggungjelasan atau akuntabilitas (disamping akuntabilitas keuangan) dan untuk mencapai tujuan organisasi (Ahyaruddin \& Akbar, 2016). Sistem pengukuran kinerja sendiri menjadi permasalahan di pemerintahan Indonesia termasuk di Daerah Istimewa Yogyakarta (Primarisanti \& Akbar, 2015). Meskipun sudah disusun sebuah sistem bernama Sistem Akuntabilitas Kinerja Instansi Pemerintah (SAKIP).

Adanya isu dan temuan tersebut menarik perhatian peneliti untuk mengkaji penerapan SPM tersebut di BPBD Daerah Istimewa Yogyakarta (DIY). Hal ini mengingat DIY memiliki sejumlah potensi bencana sehingga pengelolaan bencana (salah satunya dengan penerapan proses SPM) sangat penting untuk dilaksanakan. Penelitian difokuskan pada penerapan tujuan-tujuan yang telah ditetapkan oleh Rencana Pembangunan Jangka Menengah (RPJM) DIY melalui SAKIP, sejalan dengan posisi BPBD sebagai Organisasi Perangkat Daerah (OPD, dahulu disebut Satuan Kerja Perangkat Daerah atau SKPD) di DIY. Melalui hal tersebut dapat diketahui apakah sistem pengukuran kinerja di BPBD DIY telah membentuk keselarasan tujuan (goal congruence) sesuai dengan yang ditetapkan.

Berdasarkan uraian latar belakang di atas, terdapat isu menarik pada penerapan sistem pengukuran kinerja di BPBD DIY. Hal ini mengacu pada penelitian sebelumnya yang menyebutkan bahwa sistem pengukuran kinerja di Indonesia tidak dimaksimalkan penggunaannya (Akbar, Pilcher, \& Perrin, 2015). Berdasarkan hasil penelitian tersebut, timbul permasalahan apakah sistem pengukuran kinerja yang tercermin dalam indikator kinerja sudah dimaksimalkan penggunaannya oleh BPBD. Dari permasalahan tersebut, diperlukan sebuah evaluasi menggunakan alat analisis cetak biru kinerja (performance blueprint) yang merupakan analisis kesesuaian indikator kinerja berbasis model logika (logic model) dan diperluas dengan analisis empat kuadran Friedman. Selanjutnya, perlu dilakukan identifikasi atas faktor-faktor yang mungkin mendukung atau menghambat penyusunan indikator kinerja di BPBD DIY. Mengacu pada rumusan masalah, peneliti menyusun pertanyaan penelitian berikut: (1) Bagaimana hasil evaluasi indikator kinerja di BPBD DIY ditinjau dari alat analisis cetak biru kinerja (performance blueprint); (2) Apa sajakah faktor-faktor yang hadir dalam penyusunan indikator kinerja BPBD DIY.

\section{METODE PENELITIAN}

Penelitian ini didesain menggunakan pendekatan deskriptif kualitatif. Secara konseptual, pendekatan deskriptif bertujuan untuk men- 
deskripsikan karakteristik, aspek, serta fenomena atas subjek yang diteliti (Sekaran \& Bougie, 2013) sedangkan pendekatan kualitatif dipilih agar penelitian mampu memberikan pemahaman proses dan fenomena yang diangkat sebagai permasalahan. Subjek dalam penelitian ini adalah organisasi sektor publik yaitu Badan Penang-gulangan Bencana Daerah (BPBD) Daerah Istimewa Yogyakarta. Secara spesifik, narasumber atau partisipan penelitian ini adalah pegawai BPBD DIY yang menangani SAKIP (bidang Program, Data, dan Informasi) serta pelaksana program/kegiatan yakni pegawai seksi atau bidang. Pemilihan sampel dalam penelitian ini mengacu pada saturasi yang dicukupkan apabila sudah tidak ada tilikan atau temuan baru dari partisipan atau narasumber (Creswell, 2014, hal. 189).

Adapun teknik pengumpulan data yang dilakukan adalah (1) Dokumentasi, yaitu mencari data mengenai hal-hal atau variabel yang berupa catatan, transkrip, buku, maupun surat kabar, (Arikunto, 2010) di mana dokumen yang dianalisis adalah dokumen SAKIP BPBD DIY tahun 2017; (2) Wawancara mendalam, yang dilakukan untuk mendapatkan tilikan (insight) spesifik atas topik yang melibatkan terwawancara dengan pewawancara (Hennink, Hutter, \& Bailey, 2011) dengan mewawancarai sejumlah pegawai BPBD DIY mengacu pada pedoman wawancara yang disusun berdasarkan hasil analisis dokumen SAKIP BPBD DIY tahun 2017; serta (3) Studi Pustaka, berupa kajian dan penyelidikan data-data melalui beberapa referensi dan literatur yang peneliti gunakan untuk mengidentifikasi faktor pendukung atau kesuksesan pengukuran kinerja di instansi publik, khususnya di Pemerintah Daerah Istimewa Yogyakarta berdasarkan hasil penelitian sebelumnya. Melalui ketiga metoda tersebut, peneliti melakukan triangulasi untuk mengecek atau membandingkan keabsahan data (Moleong, 2014, hal. 330) dengan cara triangulasi sumber, metoda, penyidik, dan teori.
Tahapan analisis data mengikuti tahapan evaluasi kinerja cetak biru kinerja atau performance blueprint. Pertama, peneliti mengidentifikasi kesesuaian indikator kinerja dengan model logika.

Pada tahapan kedua, penelitian ini melakukan evaluasi indikator kinerja dengan analisis empat kuadran Friedman. Selanjutnya, pengukuran keluaran ke dalam kategori upaya dan hasil akan menentukan jenis munculan: apakah berbasis kegiatan pelayanan (service delivery) ataukah komunitas atau masyarakat (community). Selain keluaran dan munculan, komponen aktivitas dalam model logika juga ditambahkan dengan mengidentifikasi penerima manfaat langsung dan tidak langsung (sasaran, contohnya masyarakat) dengan penyedia layanan (vendor, penyedia, kolaborator, dan sebagainya). Adapun gambaran dari cetak biru kinerja diilustrasikan pada Gambar 1.

Setelah evaluasi menggunakan cetak biru selesai, peneliti selanjutnya melakukan analisis hasil wawancara. Hasil wawancara dianalisis menggunakan teknik analisis kualitatif Hutter-Hennink yang terdiri dari (1) pendeskripsian, (2) perbandingan, (3) kategorisasi, (4) konseptualisasi koda. Hasil wawancara juga berguna untuk mengetahui apakah terdapat fenomena isomorfisma kelembagaan di dalam organisasi.

\section{HASIL DAN PEMBAHASAN}

Berdasarkan perolehan data, peneliti akan memasukkan data-data tersebut ke dalam model logika yang tercantum pada gambar 2. Selanjutnya, peneliti akan mengurutkan data yang disusun dengan model logika secara urut dari kiri ke kanan, dimulai dari sumber daya hingga dampak.

Komponen sumber daya meliputi (1) anggaran, (2) pegawai, (3) relawan, (4) peralatan, dan (5) sistem pelaporan. Dasar peneliti menempatkan komponen (1) sebagai sumber daya didasarkan pada data dan pemaparan anggaran pada Eselon 2

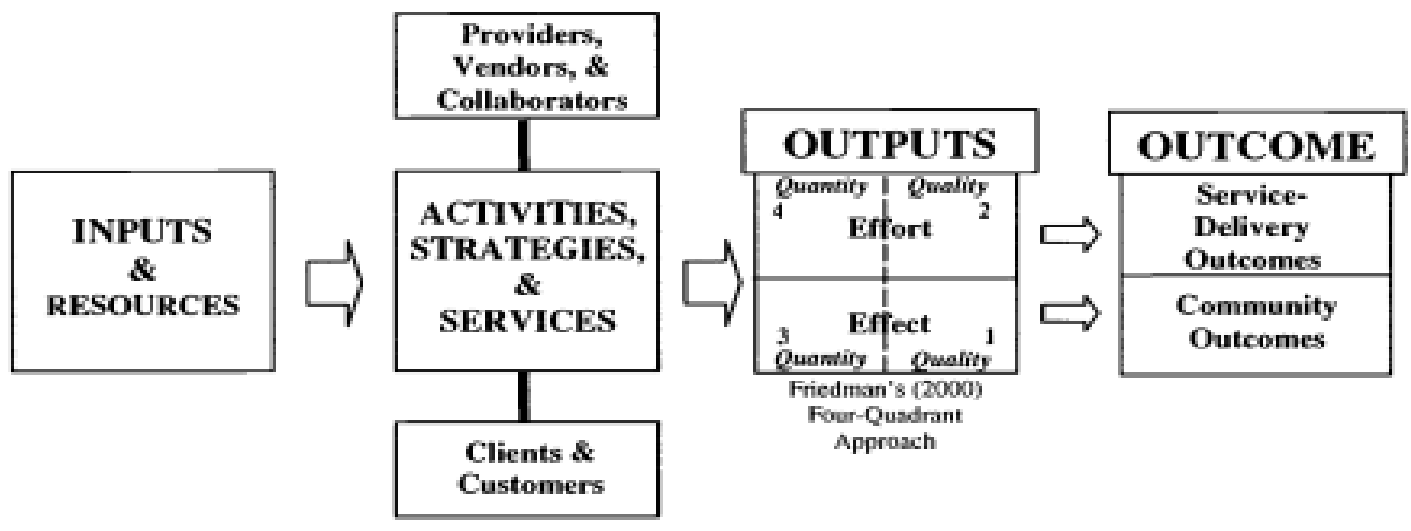

Gambar 1. Cetak Biru Kinerja (Longo, 2002) 


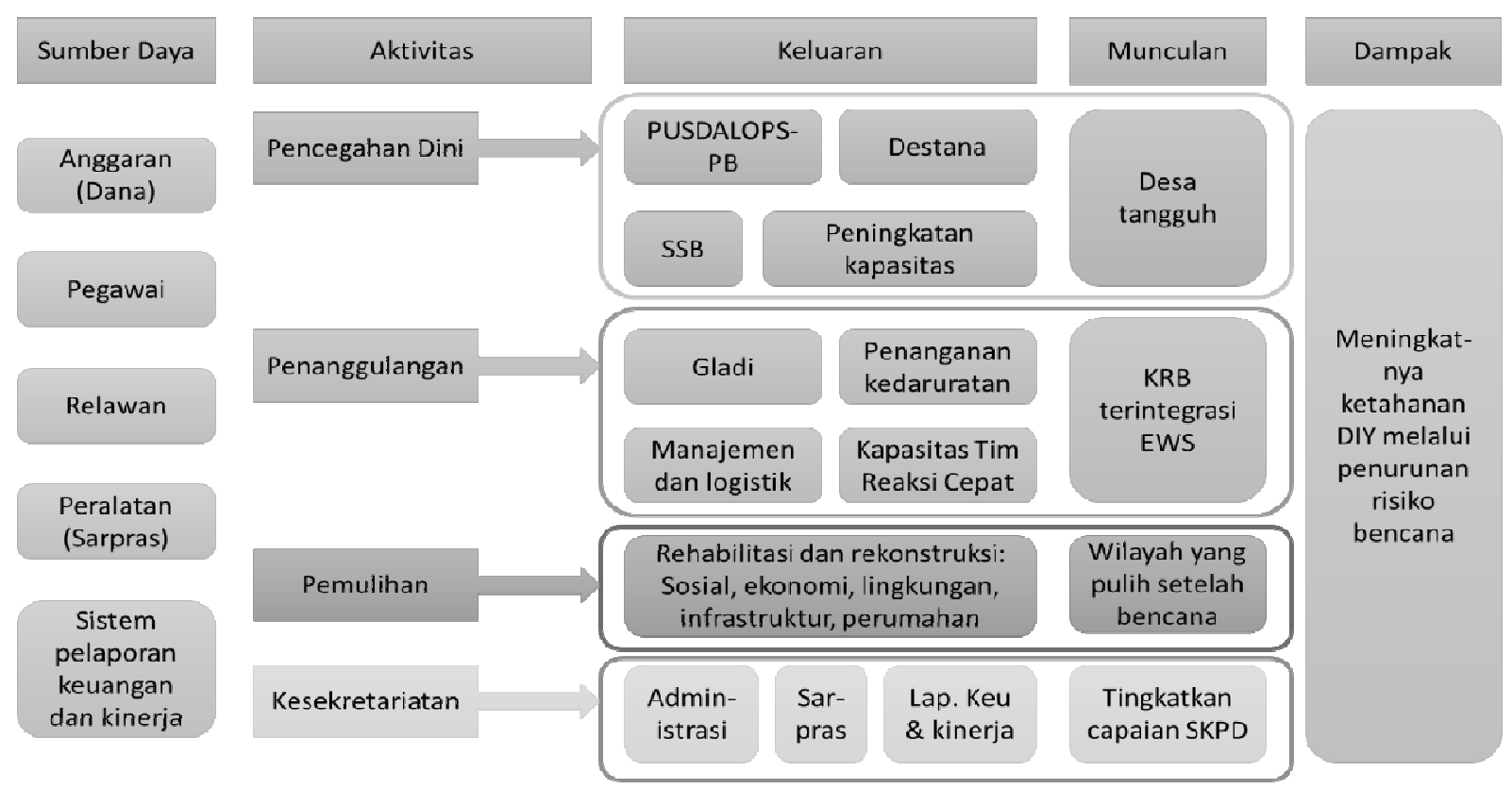

Gambar 2. Model Logika Indikator Kinerja BPBD

yang membuktikan bahwa BPBD DIY memiliki anggaran dana yang dapat dialokasikan untuk merealisasikan program dan kegiatannya. Selanjutnya, komponen (2) didasarkan pada akal sehat bahwa setiap organisasi memiliki pegawai atau sumber daya manusia. Selain itu, data dari laman BPBD DIY sendiri menyebutkan bahwa terdapat sumber daya manusia yang dimiliki oleh entitas sebanyak 50 orang yang mengacu pada data tahun 2013 (www.bpbd.jogjaprov.go.id, 2013). Komponen (3) yakni relawan, didasarkan pada data Program, Kegiatan, dan Indikator Kinerja BPBD DIY. Data tersebut menyebutkan adanya relawan dalam indikator kinerja kegiatan. Keberadaan relawan akan membantu pelaksanaan tanggap darurat apabila terjadi bencana di satu hari nanti. Atas dasar itulah, peneliti menempatkan relawan sebagai sumber daya entitas. Komponen (4) yakni peralatan, didasarkan pada pengamatan langsung peneliti di lingkungan BPBD DIY. Salah satu contoh peralatan tersebut yakni kendaraan. Komponen (5) yakni sistem pelaporan keuangan dan kinerja, didasarkan pada pengamatan peneliti langsung terhadap dua hal. Hal pertama yaitu keberadaan situs Jogja Kendali yang berfungsi sebagai "Sistem Informasi Pengendalian Pemerintah Daerah Daerah Istimewa Yogyakarta" di mana terdapat aplikasi e-SAKIP dan Monitoring dan Evaluasi (Monev) Anggaran Pendapatan dan Belanja Daerah (www.monevapbd. jogjaprov.go.id, 2017). Hal kedua adalah pengamatan peneliti saat melakukan wawancara di mana peneliti melihat narasumber pertama memasukkan data monev dan/atau SAKIP ke dalam aplikasi daring tersebut. Keberadaan sistem pelaporan yang tercermin dalam aplikasi tersebut yang menjadi basis peneliti untuk memasukkan tia ke dalam sumber daya.

Adapun komponen dalam aktivitas, keluaran, dan munculan semuanya mengacu pada konsep manajemen risiko bencana yang terdiri atas mitigasi dan kesiapsiagaan, respons, serta reha-bilitasi dan pemulihan (Louw \& Wyk, 2016). Meretia kemudian tercermin dalam tiga bidang BPBD DIY beserta program, kegiatan, dan indikator kinerjanya (yang terdiri atas aktivitas pencegahan dini, penanggulangan saat terjadi bencana, dan pemulihan). Adapun komponen kesekretariatan mencerminkan bagian sekretariat yang memegang peranan penting sebagai pendukung pencapaian skor LAKIP OPD dan Pemerintah Daerah sesuai target dalam penjabaran RPJMD DIY. Ditinjau dari sisi manajemen strategik, bagian sekretariat memiliki peran sebagai aktivitas pendukung dalam rantai nilai organisasi (Gamble, Peteraf, \& Thompson, 2015). Adapun untuk komponen dampak, peneliti menyesuaikannya dengan visi dan tujuan BPBD DIY.

Berdasarkan model logika yang telah disusun, penelitian ini menelaah bahwa program dan kegiatan yang disusun oleh BPBD DIY memiliki kesesuaian logis dari sumber daya, aktivitas, keluaran, munculan, hingga dampak. Meski begitu, ada komponen yang belum menunjukkan kesesuaian logis. Komponen tersebut ialah munculan pertama yakni desa tangguh. Pertanyaan penelitian ini terkait alasan BPBD DIY menetapkan munculan pertamanya desa tangguh, padahal secara umum diketahui bahwa daerah yang ada pada DIY tidak hanya desa saja, tetapi juga perkotaan yang melingku- 


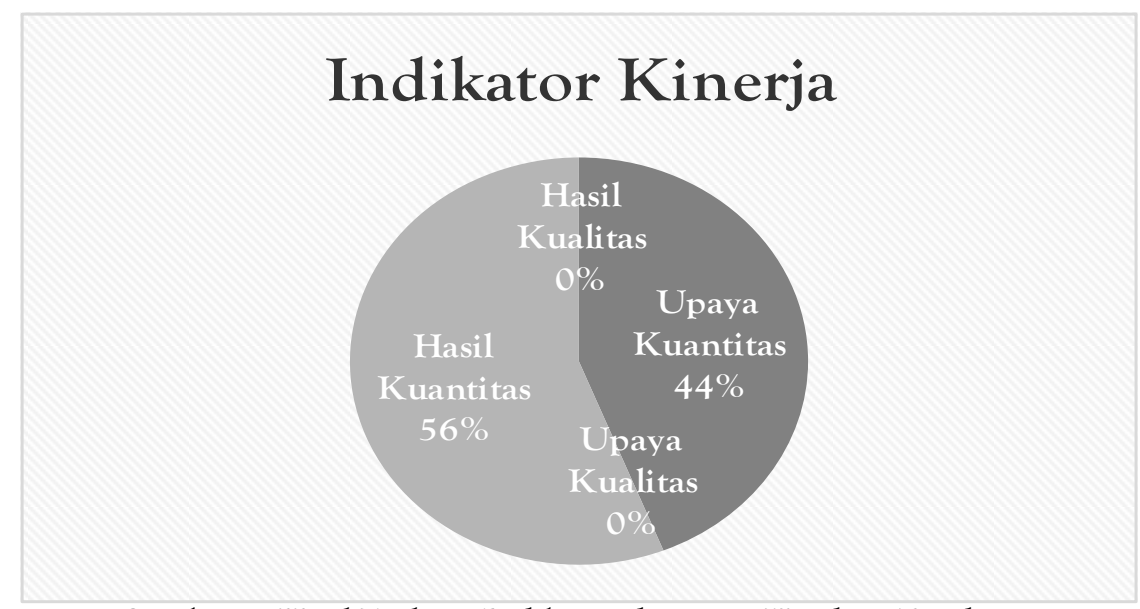

Gambar 3. Hasil Evaluasi Indikator dengan 4 Kuadran Friedman

pi kelurahan-kelurahan. Setelah melakukan pemetaan indikator dengan model logika, langkah selanjutnya adalah mengevaluasi indikator kinerja instansi menggunakan alat empat kuadran Friedman. Evaluasi ini merupakan rangkaian dari evaluasi melalui cetak biru kinerja. Penelitian ini mengevaluasi indikator kinerja BPBD DIY mengacu pada perolehan data. Hasil dari evaluasi dengan empat kuadran yang tersaji pada Gambar 3.

Berdasarkan Gambar 3, dapat diperhatikan bahwa keseluruhan indikator kinerja yang disusun BPBD DIY merupakan indikator kuantitas. Indikator kuantitas upaya sebanyak 25 (44\%) sedangkan indikator kuantitas hasil sebanyak 32 (56\%). Hal ini didasarkan dari data yang menunjukkan bahwa satuan indikator yang tertera dalam penetapan kinerja dinyatakan dalam satuan jumlah, misalnya jumlah orang hadir, jumlah sarana, dokumen, buku, dan sebagainya. Tidak terdapat indikator kualitas baik dari sisi upaya maupun hasil.

Setelah identifikasi dengan empat kuadran Friedman, langkah selanjutnya adalah evaluasi cetak biru kinerja secara keseluruhan yang belum teridentifikasi dari pembahasan sebelumnya. Artinya, evaluasi dalam bahasan ini menggabungkan evaluasi-evaluasi dalam bahasan sebelumnya yakni evaluasi berdasarkan model logika dan evaluasi berdasarkan analisis empat kua-dran Friedman. Namun begitu, evaluasi dengan cetak biru kinerja menambahkan komponen lagi selain kedua alat tersebut yakni identifikasi penerima manfaat dengan penyedia layanan berkaitan dengan aktivitas.

Hasil identifikasi dari telaah dokumen adalah sebagai berikut: Penerima manfaat (selaku sasaran) adalah masyarakat dan aparat di DIY (tujuan instansi), wilayah terdampak bencana (program nomor 3), dan Relawan dan taruna (program nomor 2). Sedangkan penyedia layanan pada dokumen tidak tertulis. Berdasarkan identifikasi, instansi berhasil menyusun indikator yang menyebutkan penerima manfaat atas aktivitas yang dihasilkan. Akan tetapi, tidak menyebutkan penyedia layanan. Selanjutnya, indikator kinerja yang disusun oleh BPBD DIY lebih condong pada munculan (outcome) yang berbasis dampak untuk masyarakat ketimbang pelayanan (service delivery), meskipun hanya terpaut tujuh indikator. Hal ini memang sesuai dengan tujuan yang telah ditetapkan dalam penjabaran RPJMD yakni untuk meningkatkan ketahanan masyarakat Daerah Istimewa Yogyakarta. Namun perlu diingat bahwa indikator yang disusun masih berupa kuantitas sehingga tingkat aktivitas yang dilakukan instansi dengan manfaat yang dirasakan masyarakat belum dapat terukur secara matematis, sebagaimana keunggulan dalam indikator kualitas upaya dan hasil (Longo, 2002).

Berdasarkan pemaparan di atas, peneliti dapat meringkas bahwa berdasarkan hasil evaluasi cetak biru, indikator kinerja yang disusun BPBD DIY memiliki kesesuaian logis serta munculan yang berbasis pada dampak untuk masyarakat. Namun, indikator BPBD DIY belum berorientasi pada kualitas baik upaya maupun hasil serta belum mengidentifikasi penyedia layanan.

Kemudian, perlu diketahui bahwa indikator kinerja yang telah dievaluasi harus dikaji dan ditelaah lebih lanjut. Hal ini untuk menyelidiki proses pelaksanaan penyusunan indikator kinerja terdapat faktor-faktor yang muncul. Berdasarkan kedua permasalahan tersebut, penelitian ini memaparkan lebih lanjut di dalam identifikasi faktor yang didasarkan pada wawancara peneliti.

Penelitian ini mewawancarai sejumlah narasumber selaku pegawai di BPBD DIY. Dua narasumber berasal dari Subbagian Program, Data, dan Informasi (PDTI) serta satu narasumber dari Seksi Pencegahan. Melalui narasumber ini, perolehan data peneliti telah mencapai saturasi yang tercermin dalam jawaban narasumber atas pertanyaan penelitian beserta pemaparan tambahannya. 
Penelitian ini juga melakukan konfirmasi atas pernyataan salah satu narasumber dan ditemukan kecocokan. Salah satu kecocokan itu adalah pernyataan salah satu narasumber yang menyatakan bahwa pegawai di seksi tidak begitu memahami secara rinci hal-hal terkait SAKIP. Setelah peneliti mewawancarai narasumber ketiga selaku pegawai seksi, hal tersebut benar bahwa pegawai tersebut memahami gambaran SAKIP tetapi tidak menguasai secara rinci SAKIP. Berdasarkan transkrip dan catatan wawancara yang telah disusun, penelitian ini menggunakan transkrip untuk menyusun koda beserta deskripsinya.

Koda E-SAKIP. Koda e-SAKIP disusun berdasarkan temuan penulis atas adanya aplikasi daring untuk mengisi LAKIP seluruh OPD di Daerah Istimewa Yogyakarta. Aplikasi tersebut di akses melalui laman monevapbd.jogjaprov.go.id. Jadi, eSAKIP memiliki konteks aplikasi daring dan bermakna sebagai media atau alat pelaporan kinerja instansi kepada pihak yang memiliki kepentingan atau kebutuhan atas informasi kinerja tersebut (dalam hal ini Gubernur dan Badan Pembangunan Daerah). Selain itu, penelitian terdahulu menyebutkan bahwa keterbatasan sistem informasi berdampak signifikan bagi penggunaan informasi kinerja OPD (Primarisanti \& Akbar, 2015). Koda ini sering kali disebutkan oleh dua narasumber dari subbagian Program, Data, dan Teknologi Informasi (PDTI). Koda ini berinterseksi dengan koda Durasi, Bantuan, Gambaran, Manfaat, Bappeda, Gubernur, dan Monev.

Koda Durasi. Makna dari koda ini adalah persepsi narasumber konteks masa pelaporan LAKIP. Peneliti ingin mencari tahu apakah durasi waktu pelaporan dirasakan pegawai pendek, mencukupi, atau panjang. Berdasarkan hasil wawancara peneliti menemukan bahwa dengan adanya e-SAKIP, durasi atau tenggat waktu pelaporan dirasa cukup untuk laporan bulanan. Hal ini dikonfirmasi dalam pernyataan berikut: "Untuk yang rutin bulanan nggak memaksa karena 10 hari..." (Pegawai Subbagian Program, Data, dan Teknologi Informasi BPBD DIY). Meski begitu, narasumber merasakan bah-wa penyusunan laporan triwulanan dirasa agak mendesak waktunya karena tenggat waktu pengumpulan harus selesai pada tanggal 5 . Koda ini berinterseksi dengan e-SAKIP, Monev, Bappeda, dan Gubernur.

Koda Pendampingan. Makna dari koda ini adalah adanya bantuan dari instansi lain apabila pengisi atau pengguna SAKIP memiliki kesulitan dalam pengisiannya. Koda ini disusun berdasarkan temuan dari penelitian Ahyaruddin dan Akbar (2016, 15) yang menyebutkan bahwa bantuan dari instansi yang kompeten memiliki peran krusial untuk mengurangi kesalahan dan meningkatkan kesempatan organisasi mencapai kesuksesan dalam pelaporan kinerja. Koda ini berinterseksi dengan koda pelatihan dan e-SAKIP.

Koda Keluaran. Konteks keluaran di sini adalah keluaran sebagai indikator kinerja kegiatan di tingkat subbagian dan seksi serta keluaran dalam konteks model logika yang peneliti susun. Koda ini disusun untuk meng-gali pemahaman personel seksi terkait yang menjadi narasumber penelitian. Responden ketiga memiliki pemahaman mengenai keluaran dan munculan seksinya terhadap sasaran RPJMD DIY yakni Indeks Ketahanan Daerah (sasaran ini menjadi komponen dampak dalam model logika peneliti). Pemaparan narasumber ketiga tentang keluaran dan munculan seksi tersebut juga mengonfirmasi pernyataan nara-sumber pertama dan kedua yang menyatakan bahwa responden memiliki pemahaman program atau kegiatan. Kode ini berinterseksi dengan koda e-SAKIP, munculan, dan dampak.

Koda Munculan. Konteks dari penyusunan koda ini sama dengan koda keluaran, meskipun secara pemaknaan atau definitif berbeda. Melalui koda ini, pemahaman narasumber ketiga terkait komponen SAKIP terkonfirmasi. Responden ketiga memiliki pemahaman mengenai keluaran dan munculan seksinya terhadap sasaran RPJMD DIY yakni Indeks Ketahanan Daerah (sasaran ini menjadi komponen dampak dalam model logika peneliti). Pemaparan narasumber ketiga tentang keluaran dan munculan seksi tersebut juga mengonfirmasi pernyataan narasumber pertama dan kedua yang menyatakan bahwa responden memiliki pemahaman program atau kegiatan. Koda ini berinterseksi dengan koda e-SAKIP, keluaran, dan dampak.

Koda Dampak. Konteks dari penyusunan koda ini sama dengan dua koda yang dijelaskan sebelumnya. Berdasarkan hasil wawancara, peneliti menemukan perbedaan define-tif antara pemahaman narasumber ketiga dengan hasil dokumentasi peneliti. Narasumber menyebutkan bahwa dampak (impact) yang ditentukan sebagai berikut:

"Dampaknya adalah meningkatnya kapasitas untuk menghadapi bencana." (Pegawai Seksi Pencegahan BPBD DIY).

Padahal, model logika yang berbasis dari dokumen SAKIP BPBD menyebutkan "meningkatnya ketahanan DIY melalui penurunan risiko bencana". Tia sesuai sebagaimana disampaikan oleh narasumber kedua sebagaimana dalam percakapan berikut: "Ya tidak semua paham bahwa ini untuk SAKIP memang." (Pegawai Subbagian Program, Data, dan Teknologi Informasi BPBD DIY). 
Pernyataan ini pun sudah disampaikan oleh narasumber pertama bahwa rekan-rekan di luar seksi PDTI tidak begitu mengetahui teknis SAKIP meskipun untuk program dan kegiatannya seksiseksi tersebut memahaminya dengan baik. Meski begitu, perbedaan definitif dari narasumber dengan model logika ini memiliki konteks yang sama. Dengan kapasitas yang meningkat, otomatis risiko bencana akan menurun. Berdasarkan meretia penelitian ini menganalisis bahwa pegawai yang tidak menangani SAKIP tidak mengetahui secara terinci teknis SAKIP (seperti hafal tujuan atau dampak kata per kata), akan tetapi substansi dari SAKIP tetap diketahui oleh pegawai. Koda ini berinterseksi dengan koda e-SAKIP, keluaran, dan munculan.

Koda Gambaran. Koda ini bermakna gambaran dari narasumber terkait kemampuan SAKIP atau LAKIP dalam menggambarkan kinerja sesungguhnya. Koda ini menjadi pertanyaan dalam pedoman wawancara, yang berbasis dari hasil wawancara dengan seorang pegawai pemerintahan yang menyebutkan bahwa LAKIP tidak merefleksikan kinerja sesungguhnya (Primarisanti \& Akbar, 2015, hal. 66). Berdasarkan hasil wawancara, narasumber pertama menyebutkan bahwa SAKIP jelas-jelas menggambarkan kinerja sesungguhnya. Meski begitu, narasumber kedua sedikit berkata lain sebagai berikut,

"Tidak terlalu, karena adanya perubahan.

Menurut saya cenderung disesuaikan, misalnya 20 lalu tidak me-mungkinkan lalu menjadi 15."

(Pegawai Subbagian Program, Data, dan Teknologi Informasi BPBD DIY).

Perubahan yang dimaksud di sini adalah perubahan atas indikator dan capaian kinerja yang ditetapkan di awal dengan yang dilaporkan di akhir tahun. Perubahan ini biasa terjadi sebelum diterapkannya e-SAKIP. Dengan adanya e-SAKIP, kinerja tercatat tiap bulan dan perubahan atau penyesuaian tidak bisa sembarangan dilakukan. “...karena selalu tercatat tiap bulan kita melaporkan kerja. Jadi walau ada perubahan tidak bisa sembarangan karena sudah tercatat di aplikasi. Dulu 'kan bisa seenaknya. Sekarang sudah mencer-minkan (dengan adanya eSAKIP, -peneliti)." (Pegawai Subbagian Program, Data, dan Teknologi Informasi BPBD DIY). Koda ini berinterseksi dengan koda e-SAKIP dan manfaat.

Koda Manfaat. Koda ini memiliki konteks pada manfaat yang dirasakan dari adanya SAKIP, khususnya e-SAKIP. Berdasarkan hasil wawancara, narasumber menyebutkan bahwa SAKIP memberi manfaat sebagai berikut.

"Manfaat yang dirasakan dari LAKIP adalah mempermudah dan pengukurannya jelas." (Pegawai Subbagian Program, Data, dan Teknologi Informasi BPBD DIY).
"Kesan saya terhadap e-SAKIP adalah enak, jadi terukur, dan ada alat untuk evaluasi." (Pegawai

Seksi Pencegahan BPBD DIY)

Koda ini berinterseksi dengan koda e-SAKIP dan gambaran. Selanjutnya, peneliti akan menjabarkan keenam koda induktif sebagai berikut.

Selanjutnya, koda yang kesembilan yaitu monev. Monev merupakan akronim dari Monitoring dan Evaluasi. Monev sendiri adalah aktivitas pemantauan Pemerintah Daerah (dalam hal ini Gubernur dan atau Badan Perencanaan Pemba-ngunan Daerah (Bappeda)) atas pencapaian OPD dalam jangka waktu bulan/triwulan. Koda ini berdasarkan transkrip hasil wawancara dengan narasumber.

"Ada monev yang diadakan triwulanan..."

(Kepala Subbidang Program, Data, dan

Teknologi Informasi BPBD DIY)

Ketiga narasumber menyinggung keberadaan monev ini. Keberadaan monev telah menjadi alat kendali bagi organisasi untuk mengarahkan program dan kegiatan. Selain itu, monev juga "mencicil kerja" penyusunan laporan kinerja yang ada di dalam SAKIP. Hal ini dikonfirmasi dalam pernyataan narasumber berikut.

“...menjadikan terprogram, terencana, dan terjadwal." (Pegawai Seksi Pencegahan BPBD

DIY).

Monev dapat dilaksanakan di dalam eSAKIP. Jadi, manfaat yang dirasakan dengan adanya e-SAKIP juga dirasakan dengan adanya monev. Koda ini berinterseksi dengan e-SAKIP, Bappeda, dan Gubernur.

Koda Pelatihan. Pelatihan di sini memiliki dua konteks, yaitu pelatihan untuk meningkatkan pemahaman pegawai tentang LAKIP atau pelatihan e-SAKIP. Langkah awal adalah menyusun terlebih dahulu koda ini dalam konteks yang pertama. Namun saat wawancara, narasumber yang bertugas untuk pengisian SAKIP (pegawai di subbagian Program, Data, dan Teknologi Informasi) benarbenar telah menguasai LAKIP. Seiring berlangsungnya wawancara, narasumber menyebutkan bahwa pelatihan yang diselenggarakan adalah pelatihan untuk pengisian e-SAKIP. Berdasarkan hal tersebut, peneliti memu-tuskan untuk menggolongkan koda ini sebagai koda induktif.

"Setiap tahun sudah ada dari Badan Diklat dan BPPKA biasanya ada pelatihan bimtek tiap tahun" (Pegawai Subbagian Program, Data, dan Teknologi Informasi BPBD DIY).

Temuan ini dikonfirmasi oleh penelitian sebelumnya yang menyebutkan bahwa pelatihan memiliki dampak positif pada pengembangan sistem pengukuran kinerja (Primarisanti \& Akbar, 2015, hal. 59). Koda ini berinterseksi dengan koda eSAKIP dan pendampingan. 
Koda Bappeda. Bappeda merupakan akronim dari Badan Perencanaan Pembangunan Daerah. Konteks Bappeda dalam koda ini adalah Bappeda Daerah Istimewa Yogyakarta. Bappeda adalah instansi yang menyusun RPJMD dan meminta laporan dari tiap OPD dalam jangka waktu tertentu. Hal ini tercermin dalam pernyataan narasumber berikut.

"...misal tanggal 5 (laporan-peneliti) sudah harus selesai karena permintaan Bappeda" (Pegawai Subbagian Program, Data, dan Teknologi Informasi BPBD DIY).

Koda Gubernur. Gubernur yang dimaksud adalah Gubernur DIY, yakni Sri Sultan Hamengku Buwono X. Saat melakukan wawancara, peneliti menemukan fakta bahwa laporan yang disusun akan dipratinjau oleh Gubernur. Hasil pratinjau tersebut meliputi pula penilaian atas kinerja OPD. Penilaian kinerja OPD kemudian akan diperingkat dari yang terbaik hingga yang terburuk, di mana kepala OPD peringkat teratas dan ter-bawah akan mendapat kesempatan untuk ber-salaman kepada Gubernur di sebuah acara stasiun televisi sebagai bentuk 'hadiah dan hukuman' atas kinerjanya. Koda ini berinterseksi dengan Bappeda, monev, dan eSAKIP. Hal ini tercermin dari kutipan berikut.

"Karena yang dilaporkan 'kan dirangking. Nanti rangking atas dan rangking bawah salaman dengan Sultan di TV_" (Pegawai Subbagian Program, Data, dan Teknologi Informasi BPBD DIY).

Koda Top-down. Top-down adalah model penyusunan indikator kinerja di mana atasan atau instansi yang memiliki kewenangan lebih tinggi menentukan program, kegiatan, atau anggaran yang harus dipatuhi oleh instansi di bawahnya. Berdasarkan hasil wawancara, peneliti menemukan adanya model ini yang tercermin dalam pernyataan berikut.

"Jadi waktu top-down itu perumusan kalimat tapi waktu cascading (RPJMD—peneliti) kami bersama-sama" (Pegawai Subbagian Program, Data, dan Teknologi Informasi BPBD DIY).

Sewaktu Bappeda menyusun RPJMD DIY dalam bentuk penjabaran (cascading), tia mengundang pula OPD-OPD lain untuk berpartisipasi dalam penyusunan cascading tersebut. Koda ini berinterseksi dengan koda Bappeda dan bottom-up.

Koda Bottom-up. Sama seperti koda sebelumnya, bottom-up adalah model penyusunan indikator kinerja hanya saja perbedaannya terletak pada keikutsertaan pegawai atau instansi di bawah otoritas dalam penyusunan dasar indikator kinerja. Penulis menemukan fakta bahwa BPBD DIY ternyata menggunakan model ini, baik saat penyusun- an cascading berikut:

"Jadi tetap apa ya istilahnya, tidak top down murni tapi ikut usul (urun rembuk-peneliti)"

Saat menyusun program dan kegiatan hingga level eselon 4 dan saat pelaksanaan monev serta laporan:

"Ketika bikin laporan triwulan atau bulanan "kan minta teman di seksi (untuk ikut sertapeneliti)..."(Pegawai Subbagian Program, Data, dan Teknologi Informasi BPBD DIY).

Selain koda induktif, ditemukan satu koda in vivo saat melakukan wawancara dan analisis transkrip. Koda tersebut adalah 'Destana' yang merupakan akronim dari Desa Tangguh Bencana. Destana ini merupakan pro-gram yang menjadi indikator Bidang Pencegahan dan Kesiapsiagaan. Berkaitan dengan program, responden ketiga menjawab bahwa indikator program yang berfokus pada 'desa tangguh bencana' didasarkan pada kajian bahwa 301 desa di DIY rawan bencana. Dengan kata lain, 75\% wilayah DIY rawan bencana. Pe-milihan fokus desa juga dilakukan mengingat kampung dan kelurahan tang-guh bencana merupakan tugas Dinas Sosial dan BPBD Kota Yogyakarta. Berdasarkan pemaparan dari narasumber ketiga di atas, dapat dianalisis bahwa model logika telah menunjukkan kesesuaian logis secara utuh. Selain itu, penjelasan nara-sumber yang runtut dan jelas (menurut pengamatan peneliti) menggambarkan pemahaman narasumber tersebut akan kegiatan di seksi kesiapsiagaan.

\section{Fenomena Isomorfisma dalam BPBD DIY}

Lingkungan kelembagaan memberi tekanan kepada organisasi, dan organisasi melakukan penyesuaian untuk mengejar legitimasi atas tekanan tersebut (Ashworth et al 2009). Tindakan penyesuaian yang dilakukan organisasi inilah yang selanjutnya dikenal sebagai isomorfisma ins-titusional atau kelembagaan. Isomorfisma kelem-bagaan adalah proses yang terjadi di dalam suatu organisasi untuk menyeragamkan dirinya (homo-genisasi) seperti unit lain yang mengalami kondisi yang sama (DiMaggio \& Powell, 1983). Isomorfisma kelembagaan dibagi menjadi tiga yakni (1) koersif, yang muncul dari tekanan politis atau legitimasi; (2) normatif, yang terjadi melalui profesionalisme (Akbar, Pilcher, \& Perrin, 2012, hal. 266); dan (3) mimetik, yaitu tindakan meniru instansi lainnya.

Menurut hasil penelitian terdahulu, fenomena 'kepatuhan semu' ini ditemui di sejumlah aparatur pemerintah daerah di Indonesia termasuk di DIY (Sofyani \& Akbar, 2015) di mana isomorfisma 
koersif menjadi penggerak pelaksanaan sistem pengukuran kinerja (Akbar et al., 2015).

Berdasarkan koda-koda yang telah disusun, peneliti menemukan adanya gejala isomorfisma institusional dalam sistem pengukuran kinerja BPBD DIY. Gejala tersebut ditemukan dalam koda-koda berikut:

Manfaat. Berdasarkan hasil wawancara, salah satu narasumber merasakan adanya manfaat dari SAKIP (khususnya e-SAKIP) sebagai alat pengukuran yang jelas. Kesadaran pegawai akan manfaat SAKIP ini mendukung profesionalisme dalam sistem pengukuran dan realisasi kinerja.

Top-down. Penyusunan cascading RPJMD dan program/kegiatan dilakukan oleh atasan, akan tetapi bawahan atau unit pelaksana ikut membahas sehingga tidak hanya model top-down saja yang diterapkan.

Bottom-up. Model bottom-up diterapkan pula dalam penyusunan cascading dan program atau kegiatan. Penerapan model bottom-up ini mengindikasikan bahwa pegawai memiliki kompetensi dan mumpuni dalam merealisasi target kinerja yang akan ditetapkan. Kompetensi ini juga peneliti konfirmasi melalui tingkat pendidikan pegawai yang dapat dikatakan baik (mengacu pada situs BPBD DIY).

Berdasarkan koda-koda tersebut, peneliti menemukan adanya gejala isomorfisma normatif. Keberadaan isomorfisma normatif diketahui melalui profesionalisme dan adanya kolaborasi antar pegawai (Akbar et al., 2012) yang dibuktikan melalui pemahaman narasumber saat peneliti wawancara. Selain itu, temuan isomorfisma normatif di BPBD DIY ini mendukung hasil penelitian sebelumnya yang menyatakan bahwa isomorfisma normatif terdapat di OPD di DIY (Primarisanti \& Akbar, 2015; Sofyani \& Akbar, 2015).

\section{Perbandingan dan Kategorisasi Koda}

Setelah koda disusun, tahapan siklus analitik yang selanjutnya yakni perbandingan dan kategorisasi. Perbandingan dan kategorisasi ini dilakukan untuk mengidentifikasi faktor-faktor dalam yang ada dalam penyusunan indikator kinerja BPBD DIY berdasarkan koda-koda yang sudah disusun sebelumnya. Perbandingan dan kategorisasi koda dipaparkan dalam Tabel 1.

Berdasarkan hasil kategorisasi dari Tabel 1, teridentifikasikan faktor-faktor yang muncul dalam penyusunan indikator kinerja BPBD DIY yaitu (1) dukungan, (2) persepsi, (3) pemahaman, (4) proses, dan (5) pengawasan dan apresiasi.

\section{Konseptualisasi Koda}

Berdasarkan kategorisasi kemudian disusun konseptualisasi sekaligus penjelasan atas identifikasi faktor-faktor yang muncul dalam penyusunan indikator kinerja BPBD DIY. Gambar 4 menunjukkan konsep atas kategorisasi koda-koda yang telah disusun.

Dukungan yang diberikan telah membantu BPBD DIY dalam melakukan penyusunan SAKIP, khususnya e-SAKIP. E-SAKIP sendiri peneliti kategorikan sebagai proses penyusunan SAKIP di mana salah satu komponennya yakni indikator kinerja. Indikator disusun dan dirancang bersama Bappeda dan BPBD DIY bersama-sama sehingga pelaksanaannya bersifat baik top-down maupun bottom-up. Cara penyusunan yang dikombinasi ini merupakan langkah yang efektif menurut Anthony dan Govindarajan (2007, 391) karena penyusunan dengan cara top-down saja akan menimbulkan rendahnya komitmen komponen organisasi yang akan membahayakan kesuksesan organisasi.

Keberhasilan proses penyusunan SAKIP diikuti oleh pemahaman organisasi (khususnya pegawai) terkait keluaran, munculan, dan dampak yang telah disusun. Ketiga komponen ini merupakan komponen penting di dalam SAKIP yang direalisasikan dalam program dan kegiatan masing-masing bidang atau seksi. Selain itu, persepsi pegawai tentang SAKIP juga merupakan komponen yang tidak dapat dikesampingkan, meskipun peneliti belum mengetahui bagaimana persepsi itu mempengaruhi atau memiliki hubungan dengan proses penyusunan SAKIP (hal ini harus diuji menggunakan metode statistik). Selain itu, keberadaan fenomena isomorfisma normatif dalam penyusunan indikator kinerja mendukung homogenisasi organisasi yang mempermudah keselarasan tujuan.

Guna mengoptimalkan penyusunan SAKIP (sebagai sistem pengukuran kinerja) yang memampukan keselarasan tujuan, pengawasan berperan penting. Sebagaimana dalam pembahasan sebelumnya, monev berperan dalam mencatat kinerja organisasi secara rutin sehingga kinerja dapat dilaporkan dengan mudah dan terukur. Persentase kinerja tiap bulan atau triwulan tergambarkan dengan baik. Dengan adanya monev atau laporan bulanan dan triwulanan, kemampuan LAKIP dalam menggambarkan kinerja sesungguhnya organisasi dapat ditingkatkan. Selain itu, adanya publikasi kinerja OPD yang diapresiasi oleh Gubernur DIY juga menjadikan organisasi terpacu untuk berkinerja dengan lebih baik. Ini selaras dengan temuan penelitian Primarisanti dan Akbar (2015) yang menyebutkan bahwa insentif (sebagai bentuk apre- 
Tabel 1. Perbandingan dan Kategorisasi Koda

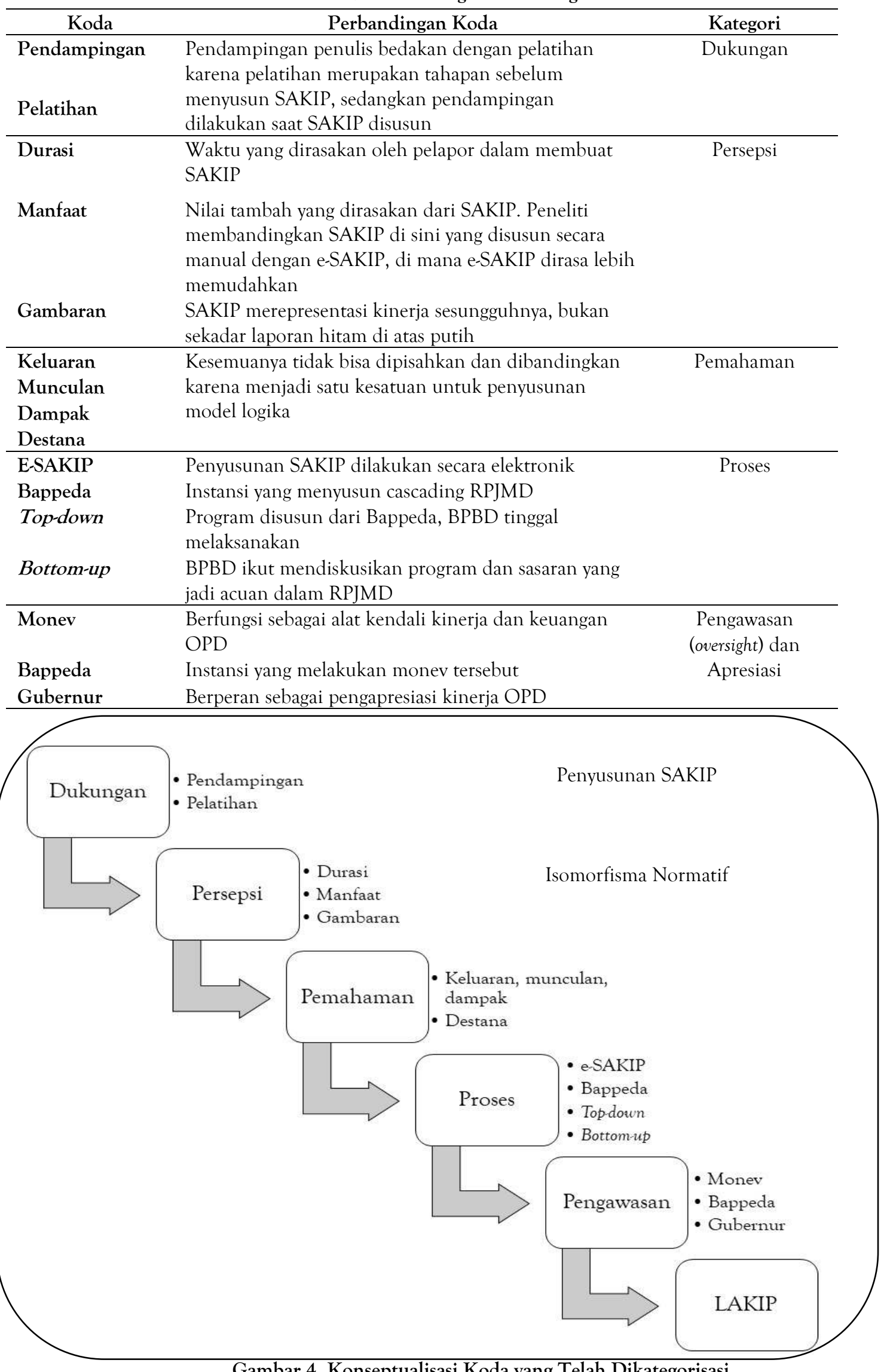

Gambar 4. Konseptualisasi Koda yang Telah Dikategorisasi 
siasi) berdampak pada peningkatan kinerja.

\section{SIMPULAN}

Berdasarkan hasil evaluasi cetak biru kinerja, peneliti menyimpulkan bahwa indikator kinerja yang disusun BPBD DIY memiliki kesesuaian logis serta munculan yang berbasis pada dampak untuk masyarakat. Namun, indikator kinerja BPBD DIY belum berorientasi pada kualitas baik upaya maupun hasil serta belum mengidentifikasikan penyedia layanan dalam aktivitasnya. Adapun munculan desa tangguh tetap terhitung menunjuk-kan kesesuaian logis karena lingkup desa di DIY sebesar 75\% dan satuan wilayah lainnya (kampung dan kelurahan) sudah menjadi fokus organisasi lain, berdasarkan hasil triangulasi dokumen dengan wawan-cara.

Selanjutnya, berdasarkan kategorisasi koda-koda yang disusun peneliti menyimpulkan terdapat beberapa faktor yang hadir dalam penyusunan indikator kinerja BPBD DIY. Faktor-faktor tersebut yakni dukungan (pendampingan dan pelatihan), persepsi, proses pembentukan, serta pengawasan dan apresiasi (monev dan "hadiah-hukuman" dari Gubernur) yang berperan bagi komponen orga-nisasi (utamanya personel) untuk menyusun SAKIP sekaligus merealisasi tujuan organisasi yakni penurunan risiko bencana. Selain itu, peneliti juga menemukan gejala isomorfisma normatif di dalam sistem pengukuran kinerja BPBD DIY.

Penelitian ini memiliki implikasi praktis pada pelaksanaan sistem pengendalian manajemen BPBD DIY, khususnya pada sistem pengukuran kinerja yang tertuang dalam e-SAKIP. Penelitian ini sekaligus memperluas hasil penelitian-penelitian sebelumnya yang menjelaskan fenomena isomorfisma institusional di berbagai OPD di Indonesia dan khususnya di DIY. Selain itu, penelitian ini menghasilkan temuan baru untuk melengkapi penelitian terdahulu yakni peran vital pengawasan dan apresiasi dalam bentuk Moni-toring dan evaluasi terhadap sistem pengukuran kinerja di seluruh OPD DIY dan secara empirik spesifik pada BPBD DIY.

Berdasarkan pemaparan dan simpulan, penelitian ini mengajukan rekomendasi sebagai berikut: (1) adanya penelitian lebih lanjut yang membahas ten-tang persepsi pegawai penggunaan e-SAKIP dan di-analisis dengan metode statistik, (2) bagi pengem-bang SAKIP DIY, peneliti merekomendasikan adanya peningkatan dan pemutakhiran fungsi e-SAKIP agar kinerja instansi dapat terukur dengan lebih baik lagi, (3) bagi BPBD DIY agar mulai mempertimbangkan menyusun indikator kinerja secara kualitatif, khususnya kualitas hasil, (4) me- ngacu pada poin 3, peneliti merekomendasikan instansi penyedia data dan atau statistik agar menyediakan data dengan seakurat dan seandal mungkin. Hal ini sangat diperlukan agar OPD dapat menyusun indikator kualitatif yang dapat diukur dengan baik, (5) bagi pemerintah daerah lain di Indonesia agar menerapkan e-SAKIP sebagaimana yang telah diterapkan di DIY supaya sistem pengukuran kinerja tiap OPD dapat tersusun dengan baik dan efektif.

\section{DAFTAR PUSTAKA}

Ahyaruddin, M., \& Akbar, R. 2016. The Relationship Between the Use of a Performance Measurement System, Organizational Factors, Accountability, and the Performance of Public Sector Organizations. Journal of Indonesian Economy and Busines, 31(1), 1-21.

Akbar, R., Pilcher, R. A., \& Perrin, B. 2015. Implementing performance measurement systems: Indonesian local government under pressure. Qualitative Research in Accounting $\mathbb{E}$ Management, 12(1), 3-33. https://doi.org/ 10.1108/QRAM-03-2013-0013

Akbar, R., Pilcher, R., \& Perrin, B. 2012. Performance measurement in Indonesia: The case of local government. Emerald Group Publishing Limited. https://doi.org/10.1108/01140581211283878

Anthony, R. N., \& Young, D. W. 2007. Management Control in Nonprofit Organizations (2nd ed.). New York: McGrawHill.

Arikunto, S. 2010. Prosedur Penelitian Suatu Tindakan Praktik. Jakarta: Rineka Cipta.

Ashworth, R., Boyne, G., \& Delbridge, R. 2009. Escape from the iron cage? Organizational change and isomorphic pressures in the public sector. Journal of Public Administration Research and Theory, 19(1), 165-187. https://doi.org/ $10.1093 / \mathrm{jopart} / \mathrm{mum} 038$

Balabonienè, I., \& Večerskienè, G. 2015. The Aspects of Performance Measurement in Public Sector Organization. Procedia - Social and Behavioral Sciences, 213, 314-320. https://doi.org/10.1016/ j.sbspro.2015.11.544

Creswell, J. W. 2014. Research Design: Qualitative, Quantitative, and Mixed Method Approaches. California: Sage Publications.

DiMaggio, P., \& Powell, W. W. 1983. The Iron Cage revisited: Collective Rationality and Institutional Isomorphism in Organizational Fields. American Sociological Review, 48(2), 147-160. https://doi.org/10.1007/s13398-014-0173-7.2

Gamble, J. E., Peteraf, M. A., \& Thompson, A. A. 
2015. Essentials of Strategic Management: The Quest for Competitive Advantage (4th ed.). New York: McGrawHill.

Halim, A. 2016. Dana Bencana. In Manajemen Keuangan Sektor Publik: Problematika Penerimaan dan Pengeluaran Pemerintah (2 ed.). Jakarta: Salemba Empat.

Hennink, M., Hutter, I., \& Bailey, A. 2011. Qualitative Research Method (1st ed.). Sage Publications.

http://bpbd.jogjaprov.go.id/web/kontent/60/sumber_ daya_manusia, diakses 3 Oktober 2017.

Longo, P. J. 2002. The Performance Blueprint, An Integrated Logic Model Developed to Enhance Performance Measurement Literacy: The Case of Performance-Based Contract Management. In Annual Conference of the American Evaluation Association. Virginia: Educational Resources Information Center (ERIC).

Louw, E., \& Wyk, S. Van. 2016. Disaster Risk Management: Planning for Resilient and Sustainable Societies. OHS Nepal, (May), 16-19.

Moleong, L. 2014. Metodologi Penelitian Kualitatif (Revisi). Bandung: Remaja Rosdakarya.

Primarisanti, H., \& Akbar, R. 2015. Factors Influencing the Success of Performance Measurement: Evidence from Local Government. Journal of Indonesian Economy and Business, 30(1), 56-71.

Rencana Nasional Penanggulangan Bencana 2015-2019: Prioritas Nasional Penanggulangan Bencana. 2014. Jakarta.

Rencana Pembangunan Jangka Menengah Nasional 2015. 2019. 2015. Jakarta.

Sasongko, A. 2014. Indonesia Supermarket Bencana. Diakses 28 Maret 2014, dari http://www.republika.co.id/berita/nasional/um um/14/03/28/n3534w-indonesia-supermarketbencana

Sekaran, U., \& Bougie, R. 2013. Research Method for Business: A Skill Building Approach (6 ed.). New York: John Wiley \& Sons.

Sofyani, H., \& Akbar, R. 2015. Hubungan Karakteristik Pegawai Pemerintah Daerah Dan Implementasi Sistem Pengukuran Kinerja. Jurnal Akuntansi dan Auditing Indonesia, 19(2), 153-173.

Undang-Undang Nomor 27 Tahun 2007 Tentang Penanggulangan Bencana, Pub. L. No. 24, 9. Negara Kesatuan Republik Indonesia. 